\title{
The Impact of Task-based Approach in Enhancing Non-English Major Students' Speaking Fluency
}

\author{
Hooshang Khoshsima \\ Chabahar Maritime University, Chabahar, Iran \\ E-mail: khoshsima@cmu.ac.ir \\ Anahita Bajool (Corresponding author) \\ Faculty of Management and Humanities \\ Chabahar Maritime University, Chabahar, Iran \\ E-mail: Bajoolana1237@gmail.com
}

$\begin{array}{lll}\text { Received: 21-08- 2014 } & \text { Accepted: 10-12- 2014 } & \text { Advance Access Published: December 2014 } \\ \text { Published: 01-05- 2015 } & \text { doi:10.7575/aiac.ijalel.v.4n.3p.16 } & \text { URL: http://dx.doi.org/10.7575/aiac.ijalel.v.4n.3p.16 }\end{array}$

\begin{abstract}
This paper sought to scrutinize the effects of tasks-based instruction on non-English major students' speaking fluency. To this aim 40 students were selected who were divided into two homogeneous groups by administering a pretest to determine their current proficiency level in speaking skill. Both control and experimental groups received the same kinds of language material. Only experimental group received material through tasks-based instruction. Findings of post test revealed significant differences between control and experimental groups in term of their speaking fluency.
\end{abstract}

Keywords: Tasks, Tasks -based language teaching, speaking skill

\section{Introduction}

\subsection{Preview}

Speaking is an active process, through which learners use their world and language knowledge to convert their thought to meaningful oral message (Chastain, P. 270). With regards to speaking skill one of the major problems of language learners is that they are not able to use language communicatively in real communicative context. According to Chastain (1988), speaking involves two major processes which are Talking to, when speaker is addressing but not interacting with listeners and Talking with, when speaker creating message and simultaneously interacting with listeners. Most language educators agree that students must know how to use language forms, they have learned, in authentic communicative context. The idea that language learning should be contextualized isn't new in language teaching because in this way the utterances are presented at discourse level rather than sentence level as it is usual in real world circumstances. As widdowson (1978) has stated normal linguistic behavior does not involve only the production of separate sentences, but the creation of discourse. So classroom activities and tasks and even instructional materials should be designed in ways that resemble real language in use. This study aims to consider the effect of task based approach along with its associated activities and classroom assignment on improving non-English students' speaking ability. In language learning process speaking plays a supporting role, vocabulary and grammatical patterns that are used in meaningful contexts through speaking will be remembered for a longer period of time. During speaking, language students need to activate their learned language elements in order to negotiate meaning through using appropriate communicative strategies.

\subsection{The statement of the problem}

It is believed that through speaking, speaker coverts his thought to oral message. Students should learn how they can transfer their learned knowledge of language in real communicative contexts. They should learn to negotiate meaning with someone who may not share one's exact experience and language back ground in order to achieve these goals. The teacher should utilize appropriate tasks in which students are involved to trigger their linguistic competence into communicative performance. In order word they should learn to put their acquired knowledge in to practice.

\subsection{Research question}

This study aims to answer the following question:

Does task -based approach affect speaking abilities of non-English major students? 


\subsection{Speaking skill as a process}

Speaking is an active process through which the learner converts language and world knowledge to meaningful message. Language students need to learn to speak in order to communicate with their classmates and participate in classroom activities. This gives them opportunities to interact with others and to negotiate meaning. Speaking also plays a critical role in learning how to use language to communicate. It's the performance of student's competence but require to be activated in some ways. Taylor (1983) stated that research illustrates that language students don't have enough ability to utilize their grammatical knowledge in real communication (as cited by Chastain, 1988). He supports approaches in which language students acquire language by using it rather than by saying it. Some language students don't have ability to express themselves orally. What can they do to overcome their difficulties? What can the teacher do to help students to improve their oral communication skills?

As it is true for other language skills, speaking plays various roles in language learning and in language classes. Teachers should be aware of these roles in order to attend to them all and consider speaking skill as an important element in developing other language skills.

\subsection{Different approaches toward teaching speaking ability}

It can be useful to take a trip through the story of language learning and teaching to see the role of speaking and the degree of attention paid to it as one of the significant language skill. The primary purpose of traditional approach like grammar translation approach was to prepare students to study literature. To achieve this goal, students had to learn long list of vocabulary and grammar and there was little concern with being able to communicate orally in the language. So there were few opportunities to speak the language in class. During World War II with the emergence of audiolingual approach speaking ability was more emphasized but mechanical pattern practice and teacher-centered

Classes didn't lead student to gain the ability to negotiate meaning. Evolution of cognitive approach had a great influence on language teaching, based on this approach the goal was to teach students to produce meaningful responses. Teachers understood the hierarchy of tasks in developing language skills. Comprehension approach was another approach as Chastain (1988) stated proponents of this approach claim that this approach produces superior results. But since teachers make students to speak before they are ready,they lead them to try to produce sentences by applying conscious grammar rules and consequently cause overloading of their short-term memory. A more recent example of attempts to develop a teaching methodology from learning research is referred to as task-based language teaching. Proponents of it stated that second language acquisition research shows that successful language learning is that in which all learners are involved in negotiation of meaning. According to Richards and Renandya (2002) in the process of negotiating with a speaker of target language, the learner receives the kind of input needed to facilitate learning. It is assumed that classroom tasks which involve negotiation of meaning should form the basis of the language teaching pedagogy that tasks can be used to practice both form and communicative function.

\subsection{Different kinds of tasks for speaking ability}

Prahbu (1983) initiated an extensive application of task-based approach in schools in India and devised a syllabus and associated teaching materials in order to develop communicative competence of students. He believed the development of this kind of competence relied on participation of students in meaning focused activities. Students need to learn how to negotiate meaning (Sanchez, 2004). According to Rod Ellis (2008) learners can learn naturally in communicative classroom setting. Spada and Light Bo (1989) pointed out an intensive ESL course which was presented by means of communicative methods, indicted tasks generating natural interaction. According to Nunan $(1989,1993)$ tasks compromised of six elements. The first of these is the input data, the materials that are presented to learners, for enough a radio broad cast. They also involve one or more activities, similar to real life tasks in which learners are involved to Handel the provided input. In addition they include goals, teachers' roles, learners'roles and setting(Yin Song, 2010).Terone's study (1983) operated in task-based model reveals that learners differ in their language performance on the extent to which they focus on forms, when their attention is at it 's highest point they achieve the careful style and when their attention is at it 's lowest point they eventually acquire their vernacular styles(Ridha Ben Maad,2008). Alice Omaggio Hadley states (2001) that careful style tasks contain of inter language that learner fully mastered but vernacular style tasks consist of those forms that have not fully mastered, so ;developments involve gradual progress from formal to informal task styles. According to the above mentioned observations variety of tasks should be conducted in the classroom to lead students from simple to more complex communicative tasks.

\section{Methodology}

\subsection{Introduction}

One of the major problems of language students is their inability to express themselves in real communication contexts. This study aims to investigate the impact of task-based approach of students speaking skill. An experimental design is used in this study; then participants, instruments, procedure, and data collection will be considered respectively in this chapter. 


\subsection{Instruments}

This study uses a pretest to determine students' current proficiency level in speaking skill in both experimental and control groups, then it uses a post test to measure development of members of experimental group after receiving instruction through task-based activities such as role playing or information gap in comparison to control group who don't receive any treatment with regard to task-based approach. Both of these tests are based on IBT TOEFL recommended framework for speaking test. So the validity and reliability of them have been checked in advance. The framework is introduced bellow:

Table 3.1. Assigned points to students' answers according to following criteria

\begin{tabular}{llll}
\hline 1 & Independent & Non & Describing about a past event \\
\hline 2 & $\begin{array}{l}\text { Integrated and conversation- } \\
\text { based }\end{array}$ & Reading conversation & Restate opinion of speaker \\
3 & integrated & Reading a paragraph. & Say your comment. \\
4 & $\begin{array}{l}\text { Integrated and conversation- } \\
\text { based }\end{array}$ & Listening conversation & Personalize the conversation \\
5 & Integrated & $\begin{array}{l}\text { listen about different kinds of } \\
\text { remedies }\end{array}$ & $\begin{array}{l}\text { Answer questions which one do you } \\
\text { prefer }\end{array}$ \\
\hline
\end{tabular}

\subsection{Procedures}

Each test had five items, each item included a task. Four points were assigned to each task with regard to five key points which were as following.

1. Fluency of speech.

2. Ideas are clearly explained

3. Appropriate use of vocabulary

4. Correct pronunciation

5. Correct grammar structure

Table 3.2. The criteria to measure student's speaking abilities

\begin{tabular}{|c|c|c|}
\hline score & General Prescription & Key Points \\
\hline 1 & $\begin{array}{l}\text { Speaker answers the question well; there are } \\
\text { only few mistakes with grammar structures and } \\
\text { pronunciation. }\end{array}$ & $\begin{array}{l}\text { Speech is fluent and easy to understand. Appropriate use of } \\
\text { grammar, vocabulary, idea is explained clearly. }\end{array}$ \\
\hline 2 & $\begin{array}{l}\text { Speaker answers the question, all idea aren't } \\
\text { explained clearly, there are some clearly } \\
\text { mistakes in speech. }\end{array}$ & $\begin{array}{l}\text { At least two of these problems. Pronunciation, pace of speech in } \\
\text { ability, to use appropriate vocabulary in correct grammar } \\
\text { structure. }\end{array}$ \\
\hline 3 & $\begin{array}{l}\text { Speaker answers with a short response and } \\
\text { some effort is required because speech isn't } \\
\text { fluent. There is some mistake with } \\
\text { pronunciation and ideas aren't clearly } \\
\text { explained, some incorrect use of grammar } \\
\text { structure. }\end{array}$ & $\begin{array}{l}\text { At least two of these problems. Wrong pronunciation, lack of } \\
\text { basic grammar, ideas are not explained clearly, incorrect use of } \\
\text { vocabulary. }\end{array}$ \\
\hline 4 & $\begin{array}{l}\text { The speaker's answer is very short. It is } \\
\text { difficult to understand him/her. }\end{array}$ & $\begin{array}{l}\text { At least two of these problems, ideas cannot be understood, a lot } \\
\text { of incorrect pronunciation and grammar structures, incorrect use } \\
\text { of vocabulary. }\end{array}$ \\
\hline 5 & No response or unrelated response. & \\
\hline
\end{tabular}




\section{Result and Discussion}

As it was mentioned two groups included control and experimental groups attended in this study. According to obtained numerical data which is run in SPSS software it is obvious that experimental group who received task-based instruction show greater improvement over those group who do not receive such kind of instruction. One of the major problems of many language students is their inability to express themselves in real communicative context. Since tasks and activities in which students are involved through task-based approach as proved by this study affect language students' speaking skill significantly, this study draws teacher's attention to their critical role to choose the most appropriate types of approaches, activities and strategies in order to lead their students more and more toward the goal of gaining fluent speech. Many of task-based activities encompass negotiation of meaning among learners. As a result they produce higher degree of comprehension and make learner more flexible with resort to their lexical repertoire. It is done through paraphrasing and by trying to construct more rules about the structure of language by making hypotheses and revising those hypotheses according to input received through these activities and gradually they become more competent speakers.

Table 4.1. Group statistic before the treatment

\begin{tabular}{llllll}
\hline & VAR00002 & $\mathrm{N}$ & Mean & Std. Deviation & Std. Error Mean \\
\hline VAR00001 & 1 & 20 & 12.4250 & 3.15509 & .70550 \\
& 2 & 20 & 12.2500 & 2.79332 & .62461 \\
\hline
\end{tabular}

The above table indicates that the mean scores of the experimental and control groups before the outset of the treatment are very close, which conveys that the two groups were not very much different.

Table 4.2. Independent T-test between the scores of control and experimental groups

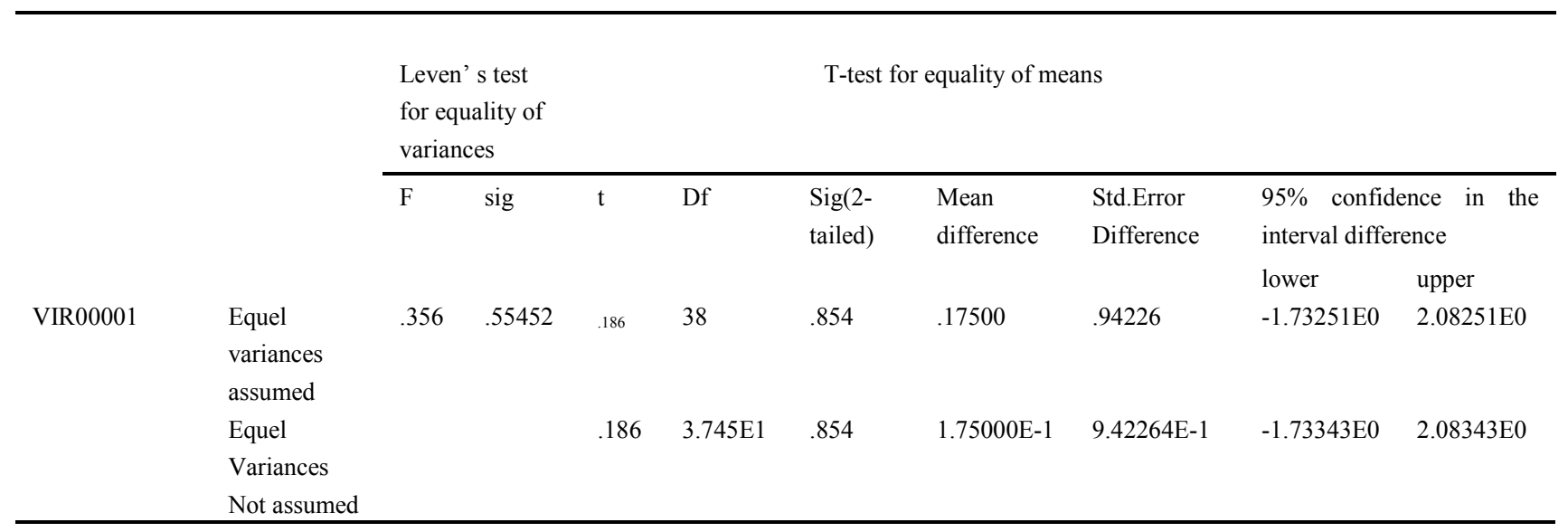

According to the above table sig $=.356>0.05$, this refers to equal variances of scores for the two groups and sig (2-tailed) $=.854>0.05$.this means that there is no significant difference between two groups before the outset of the study.

After the treatment, a post test was administered to the two groups to examine the changes of the performance of the students. The result of the independent $\mathrm{T}$-test is presented in the following table:

Table 4.3. Group statistic of the control and experimental groups after the treatment

\begin{tabular}{llllll}
\hline & VAR00004 & $\mathrm{N}$ & Mean & Std. Deviation & Std. Error Mean \\
\hline VAR00003 & 1 & 20 & 12.5500 & 3.10305 & .69386 \\
& 2 & 20 & 15.7500 & 2.66310 & .59549 \\
\hline
\end{tabular}

According to the above table there is noticeable difference with regard to speaking abilities between two groups after receiving task-based instruction. However in order to locate a significant differences it would be necessary to observe the $\mathrm{P}$ value in the next table. 


\begin{tabular}{|c|c|c|c|c|c|c|c|c|c|c|}
\hline \multirow{8}{*}{ VIR00001 } & & \multicolumn{2}{|c|}{$\begin{array}{l}\text { Leven's test } \\
\text { for equality of } \\
\text { variances }\end{array}$} & & & \multicolumn{5}{|c|}{ T-test for equality of means } \\
\hline & & \multirow[t]{2}{*}{$\mathrm{F}$} & \multirow[t]{2}{*}{ sig } & \multirow[t]{2}{*}{$\mathrm{t}$} & \multirow[t]{2}{*}{ Df } & \multirow[t]{2}{*}{$\begin{array}{l}\operatorname{Sig}(2- \\
\text { tailed })\end{array}$} & \multirow[t]{2}{*}{$\begin{array}{l}\text { Mean } \\
\text { difference }\end{array}$} & \multirow[t]{2}{*}{$\begin{array}{l}\text { Std.Error } \\
\text { Difference }\end{array}$} & \multicolumn{2}{|c|}{$\begin{array}{l}95 \% \text { confidence in the } \\
\text { interval difference }\end{array}$} \\
\hline & & & & & & & & & lower & upper \\
\hline & $\begin{array}{l}\text { Equel } \\
\text { variances } \\
\text { assumed }\end{array}$ & .471 & .497 & -3.500 & 38 & .001 & $-3.20000 \mathrm{E} 0$ & .91436 & $-5.05102 \mathrm{E} 0$ & $1.34898 \mathrm{E} 0$ \\
\hline & Equel & & & -3.500 & 37.145 & .001 & $-3.20000 \mathrm{E} 0$ & .91436 & $-5.05242 \mathrm{E} 0$ & $1.34758 \mathrm{E} 0$ \\
\hline & Variances & & & & & & & & & \\
\hline & Not & & & & & & & & & \\
\hline & assumed & & & & & & & & & \\
\hline
\end{tabular}

Table4.4 Indicates the $\mathrm{P}$ value .001 is smaller than $.05, \mathrm{P}<.05$, then the null hypothesis for the study is rejected. It can be claimed that the task-based approach could significantly improve the performance of the study in the experimental group.

\section{Conclusion}

Many language learners encounter difficulties whenever they want to make contact in real life situation. In other word they have difficulties to put their competence in to the performance. Language teacher can help students to overcome these problems by designing and providing appropriate task in language classroom as it is justified by this study. Since through tasks which are similar to real life activities, they can simulate the real life context and assist learners to prevail all potential problems that affect students' performance. Along with achieving this aim, task-based instruction enables instructors to adjust classroom instruction with students' needs and inspire learners to acquire a high level of language proficiency to satisfy their own need.

\section{References}

Ben Maad, M. R. (2008). Time Pressure and Within-task Variation in EFL Oral Performance. Electronic Journal of Foreign Language Teaching, 5-12.

Chastain, K. (1988). Developing second language skills. New York: Harcourt Brace Jovanovich ,Inc.

Ellis, R. (2008). The Study of Second Language Aquisition. New York: Oxford University Press.

Ommagio Hadley, A. (2001). Teaching language in context. Michigan: Heinle\&Heinle.

Reichard, J. C., \& Renandya, W. A. (2002). Methodology in languge teaching. Cambridge: Cambridge University Press.

Richards, J. C., \& Rodgers, t. s. (2001). Approaches and Methods in Language Teaching. Cambridge: Cambridge University Press 2001.

Richards, J. C., \& Schmidt, R. (1992). Longman Dictionary Of Language Teaching \& Applied Linguistics. London: Longman Group UK Limited 1992.

Sanchez, A. (2004). Task-based Aproach in language Teaching. International Journal of English Studeis, 39-71.

Spada, N., \& Lightbown, P. (1989). Intensive ESL Programmes in Quebec Primary Schools. TESL, 11-32.

Widdowson, H. (1978). Teaching Laguage as Communication. Oxford : Oxford University Press.

Yin Sung, K. (2010). Promoting Communicative Language Learning through Communicative Tasks. Journal of Language Teaching and Research, 704-713. 